\title{
HUBUNGAN DURASI PENGGUNAAN SMARTPHONE PADA PAGI HARI TERHADAP TINGKAT STRES MAHASISWA PROGRAM STUDI ILMU KEPERAWATAN UNIVERSITAS RIAU
}

\author{
Mohd. Ripa'i ${ }^{1}$, Safri' ${ }^{2}$, Yulia Irvani Dewi ${ }^{3}$ \\ 1,2,3PSIK Universitas Riau \\ Program Studi Ilmu Keperawatan Universitas Riau Jalan Pattimura No 9 Gedung G Pekanbaru Riau \\ Kode Pos 28131 Indonesia \\ Telepon 0823-9298-9492 email muhammadrifaiamin@gmail.com
}

\begin{abstract}
Abstrak
Smartphone merupakan sebuah perangkat yang pada awalnya hanya digunakan untuk melakukan komunikasi, kini berkembang menjadi perangkat yang hampir dapat melakukan segala hal yang menunjang aktivitas manusia. Penggunaan smartphone yang berlebihan dapat menyebabkan seseorang mengalami gangguan kesehatan mental, hal ini karena pancaran radiasi dari smartphone maupun penggunaan yang berlebihan. Penelitian ini bertujuan untuk mengetahui hubungan antara durasi pengunaan smartphone pada pagi hari terhadap tingkat stres mahasiswa keperawatan di Universitas Riau. Penelitian ini menggunakan desain deskriptif korelasi dengan pendekatan cross sectional. Sampel sebanyak 199 mahasiswa yang diambil dengan teknik stratified random sampling yang sesuai dengan kriteria inklusi. Penelitian ini menggunakan kuesioner yang telah diuji validitas dan reliabilitasnya. Analisis univariat dilakukan untuk mengetahui distribusi frekuensi dan analisis bivariat dengan uji korelasi Chi-Square. Hasil penelitian menunjukkan ada hubungan yang signifikan antara durasi penggunaan smartphone pada pagi hari terhadap tingkat stres mahasiswa dengan $p$ value $(0.000)<\alpha(0,05)$. Hal ini dapat disimpulkan bahwa terdapat hubungan antara durasi penggunaan smartphone pada pagi hari terhadap tingkat stres mahasiswa. Hasil penelitian ini diharapkan dapat menjadi sumber informasi kepada mahasiswa mengenai penggunaan smartphone untuk dapat mencegah atau meminimalkan munculnya stres.
\end{abstract}

Kata kunci: Durasi penggunaan smartphone, tingkat stres mahasiswa.

\begin{abstract}
Smartphone is a device that the content is only used to communicate, but now is developing into a device that can almost do everything to support human activity. Excessive use of smartphones can make a person has mental health problems, this is due to radiation emissions from smartphones and excessive used. This research aims to determine the relationship between the duration of smartphone use in the morning to the stress level of nursing students in the University of Riau. The design of this research was descriptive correlational with cross sectional approach. Research was conducted in school of nursing University of Riau with 199 samples were selected using proportionate stratified random sampling with inclusion criteria. This research used questionnaire that has been tested its validity and realibility. Data analysis used univariate analysis to find the frequency distribution and bivariate analysis using Chi-Square test. The results showed there was a significant relationship between the duration of smartphone usage in the morning with student stress level with $p$ value $(0.000)<\alpha(0,05)$. It can be concluded that there is a relationship between the duration of the smartphone in the morning to the student's stress level. The results of this research is a source of information for students about smartphone usage to prevent or minimize emergence of stress.
\end{abstract}

Keywords: Duration of smartphone usage, stress level of student.

\section{PENDAHULUAN}

Perkembangan teknologi melesat pada beberapa tahun terakhir, sebuah perangkat yang pada awalnya hanya digunakan untuk melakukan komunikasi, kini berkembang menjadi perangkat yang hampir dapat melakukan segala hal yang menunjang aktivitas manusia, perangkat tersebut adalah 
Mohd. Ripa'i ${ }^{1}$, Safri $^{2}$, Yulia Irvani Dewi ${ }^{3}$, Hubungan Durasi Penggunaan Smartphone pada Pagi Hari terhadap Tingkat Stres Mahasiswa Program Studi Ilmu Keperawatan Universitas Riau

smartphone. Smartphone merupakan telepon yang menyatukan kemampuan-kemampuan terdepan; ini merupakan bentuk kemampuan dari Wireless Mobile Device (WMD) yang dapat berfungsi seperti sebuah komputer dengan menawarkan fitur-fitur seperti Personal Digital Assistant (PDA), akses internet, e-mail, dan Global Positioning System (GPS). Smartphone juga memiliki fungsi-fungsi lainnya seperti kamera, video dan MP3 players. Dengan kata lain, smartphone dapat dikategorikan sebagai mini komputer yang memiliki banyak fungsi dan penggunanya dapat menggunakannya kapanpun dan dimanapun (Backer, 2010). Di lihat dari pengguna smartphone dunia yang terus mengalami peningkatan, yakni tumbuh $37 \%$ dari 1,5 miliar orang di tahun 2013 menjadi 2,1 miliar orang di tahun 2014. Kemudian meningkat $22 \%$ di tahun 2015 menjadi 2,5 miliar orang. Ini merupakan 35\% dari 7,2 miliar populasi dunia di tahun 2015 (Salam, 2015).

Pengguna smartphone di Indonesia juga bertumbuh dengan pesat. Lembaga riset digital marketing, memperkirakan pada 2018 jumlah pengguna aktif smartphone di Indonesia lebih dari 100 juta orang (Kominfo, 2013). Platform smart data untuk mobile marketing and $e$ commerce, merilis data terbaru perihal Smartphone User Persona Report (SUPR) atau laporan persona pengguna smartphone di Indonesia untuk tahun 2015. Dalam laporan tersebut pengguna smartphone direntang usia dibawah 30 tahun lebih besar, yakni sekitar $61 \%$ (Hasan, 2015). Sedangkan untuk pengguna internet di Indonesia pada akhir 2014 tercatat mencapai 88,1 juta pengguna atau meningkat $23 \%$ dibanding tahun sebelumnya sebanyak 71,9 juta. Dengan demikian, penetrasi pengguna internet di Indonesia kini naik menjadi $34,9 \%$ dari posisi sebelumnya $28,6 \%$. Mayoritas pengguna internet berusia 18-25 tahun (Kure, 2015). Dengan meningkatnya gaya hidup masyarakat modern, Indonesia kini tengah menduduki peringkat ke-5 sebagai negara dengan pengguna smartphone terbanyak di dunia. Pengguna smartphone dari masyarakat perkotaan di Indonesia sekitar $80 \%$ pengguna. Penyebabnya adalah kesadaran masyarakat akan akses informasi dan sebagian besar menjadi sarana mengekspresikan diri di media sosial (Prayogi, 2014).

Dalam sehari, seseorang dapat memeriksa smartphone sampai 34 kali bahkan lebih. Penggunaan yang berlebihan dan kebiasaan memeriksa smartphone ini yang mengakibatkan penggunaan menjadi kompulsif, bahkan menyebabkan kecanduan smartphone (Oulasvirta, Rattenbury, Ma, \& Raita, 2012). Penggunaan kompulsif dan berlebihan dapat menyebabkan gejala kesehatan mental seperti gangguan tidur dan depresi (Thomée, Härenstam \& Hagberg, 2011). Sedangkan penelitian yang dilakukan oleh Samaha dan Hawi (2016) menunjukkan adanya hubungan positif antara kecanduan 
smartphone dan stres. Jika resiko kecanduan smartphone meningkat, maka stres yang dirasakan diperkirakan juga akan meningkat. Selain gangguan tersebut, gangguan lain yang dapat terjadi adalah technostress (Charles, Piazza, Mogle, Sliwinski \& Almeida, 2013).

Technostress adalah ketidaknyamanan secara fisik maupun psikologis yang timbul akibat individu tidak bisa beradaptasi dengan kondisi teknologi informasi saat ini. Selain itu juga, individu memiliki ketergantungan yang berlebihan dengan berbagai teknologi (Nurfadilah, 2014).

Untuk pengguna smartphone, smartphone merupakan benda yang pertama kali penggunanya lihat pada pagi hari dan yang terakhir dilihat sebelum tidur (Thomee et al., 2011). Pada pagi hari, AdrenoCorticoTropic Hormone (ACTH) meningkat dan mencapai titik terendah pada saat malam hari (Bornstein, Allolio, Arlt, Barthe \& DonWauchope, 2016). Ini terjadi dalam ritme sirkadian manusia. Ritme sirkadian dapat dipengaruhi oleh cahaya, gravitasi, stimulus elektromagnetik dan lain-lain. ACTH merupakan hormon yang akan beraksi pada korteks adrenal yang kemudian akan memproduksi kortisol sebagai pemicu terjadinya stres (Breivik, 2000 dalam Boyati, 2007). Penelitian yang dilakukan oleh Mahdavi, Sahraei, Yaghmaei dan Tavakoli (2014), menemukan adanya peningkatan ACTH setelah diberikan gelombang elektromagnetik pada seekor tikus.
Peningkatan ACTH tersebut ditandai dengan gejala seperti gelisah yang mengindikasikan terjadinya stres. Stres tersebut dapat mengakibatkan teraktivasinya HypothalamicPituitary Adrenal Axis (HPA-axis). Kemudian hipotalamus yang terpicu oleh stresor akan mensekresi Corticotrophin Releasing Hormone (CRH) dan Arginin Vasopressin (AVP). Sekresi CRH akan menstimulasi korteks adrenal untuk mensekresi kortisol sebagai hormon pemicu stres (Dewi \& Wulan, 2015).

Studi pendahuluan yang dilakukan oleh Azrul (2016) di Program Studi Ilmu Keperawatan Universitas Riau (PSIK UR), dari 292 orang mahasiswa PSIK UR berusia antara 18-24 tahun, didapatkan bahwa 286 orang menggunakan smartphone dan 6 orang tidak menggunakan smartphone. Penggunaan smartphone tersering yaitu digunakan untuk chatting dan browsing. Hasil wawancara terhadap 10 orang mahasiswa angkatan 20142016 PSIK UR secara acak, ternyata semua mahasiswa adalah pengguna smartphone. Dari 10 orang yang menggunakan smartphone, semua mengaku menggunakan smartphone pada pagi hari (Pukul 04:00 - 11:00 WIB) pada 1 minggu terakhir. Durasi penggunaan antara 10-120 menit. Beberapa tanda gejala dari stres sering dirasakan ketika mereka berada di kampus, seperti mudah marah, sulit untuk bersantai, tidak sabar terhadap sesuatu, dan mudah gelisah. Walaupun ini tidak terlepas dari tugas yang ada di kampus. Oleh 
Mohd. Ripa'i ${ }^{1}$, Safri' ${ }^{2}$, Yulia Irvani Dewi ${ }^{\mathbf{3}}$, Hubungan Durasi Penggunaan Smartphone pada Pagi Hari terhadap Tingkat Stres Mahasiswa Program Studi Ilmu Keperawatan Universitas Riau

sebab itu, peneliti ingin mengetahui apakah ada hubungan durasi antara penggunaan smartphone pada pagi hari terhadap tingkat stres pada mahasiswa PSIK UR.

\section{METODE}

Penelitian ini dilaksanakan di PSIK Universitas Riau yang dimulai dari bulan Februari sampai Juli 2017. Penelitian ini merupakan sebuah penelitian kuantitatif dengan menggunakan desain penelitian deskriptif korelasi dengan pendekatan cross sectional. Penelitian deskriptif korelasi adalah suatu penelitian yang menelaah hubungan antara 2 variabel pada suatu situasi atau sekelompok subyek (Notoatmodjo, 2010). Teknik penelitian cross sectional merupakan rancangan penelitian dengan melakukan pengukuran atau pengamatan pada saat bersamaan (Hidayat, 2007).

Populasi dalam penelitian ini adalah mahasiswa Program Studi Ilmu Keperawatan Universitas Riau angkatan A2014 (1), A2014 (2), A2015 (1), A2015 (2), 2016 (1) dan 2016 (2) yang bejumlah 396 orang. Pengambilan sampling menggunakan teknik stratified random sampling dengan criteria inklusi yaitu mahasiswa yang menggunakan smartphone pada pagi hari, telah terpapar smartphone selama minimal 21 hari dan bersedia menjadi responden.

Sampel dalam penelitian ini sebanyak 199 orang yang diambil dengan menggunakan rumus Slovin (Setiadi, 2013).
Alat pengumpulan data pada penelitian ini menggunakan alat ukur kuesioner. Kuesioner berisi tentang pengkajian durasi penggunaan smartphone pagi hari dan stres mahasiswa. Kuesioner yang digunakan untuk pengukuran stres merupakan modifikasi Depression Anxiety Stress Scales (DASS), Social Readjustment Rating Scale (SRRC) dan tinjauan teori. Uji validitas dilakukan kepada 30 mahasiswa Sekolah Tinggi Ilmu Kesehatan Hangtuah Pekanbaru (STIKES HTP) dengan hasil pertanyaan valid memiliki $\mathrm{r}$ hitung antara 0,467 - 0,868 pada 18 pertanyaan yang digunakan pada penelitian dan memiliki cronbach's alpha sebesar 0,927. Analisis data menggunakan SPSS17.

\section{HASIL}

\section{Analisa univariat}

Analisa univariat dalam penelitian ini memaparkan distribusi frekuensi dan persentase tentang karakterisktik responden yang meliputi jenis kelamin dan usia, gambaran durasi penggunaan smartphone pada pagi hari dan gambaran tingkat stres mahasiswa PSIK UR.

Tabel 1

Karakteristik responden berdasarkan jenis kelamin dan usia

\begin{tabular}{ccc}
\hline Jenis Kelamin & Frekuensi (n) & Persentase (\%) \\
\hline Laki-laki & 24 & 12,1 \\
Perempuan & 175 & 87,9 \\
\hline Total & 199 & 100 \\
\hline
\end{tabular}




\begin{tabular}{ccc}
\hline Jenis Kelamin & Frekuensi (n) & Persentase (\%) \\
\hline Usia (tahun) & & \\
\hline 18 & 32 & 16,1 \\
19 & 75 & 37,7 \\
20 & 61 & 30,7 \\
21 & 31 & 15,5 \\
\hline Total & 199 & 100 \\
\hline
\end{tabular}

Tabel 1 diatas menunjukkan bahwa dari 199 responden yang diteliti, sebagian besar responden berjenis kelamin perempuan yaitu sebanyak 175 orang $(87,9 \%)$. Usia dari 199 responden yang diteliti, menunjukan rentang usia antara 18 hingga 21 tahun. Sebagian besar responden berusia 19 tahun yaitu sebanyak 75 orang $(37,7 \%)$.

Tabel 2

Gambaran durasi penggunaan smartphone pada pagi hari

\begin{tabular}{ccc}
\hline $\begin{array}{c}\text { Durasi Penggunaan } \\
\text { Smartphone pada Pagi } \\
\text { Hari }\end{array}$ & $\begin{array}{c}\text { Frekuensi } \\
(\mathbf{n})\end{array}$ & $\begin{array}{c}\text { Persentase } \\
(\boldsymbol{\%})\end{array}$ \\
\hline Durasi Singkat & 107 & 53,8 \\
Durasi Lama & 92 & 46,2 \\
\hline \multicolumn{1}{c}{ Total } & 199 & 100 \\
\hline
\end{tabular}

Tabel 2 diatas menunjukan hasil dari penelitian yang dilakukan pada 199 responden didapatkan sebagian besar responden menggunakan smartphone dengan durasi singkat, dengan jumlah 107 responden $(53,8 \%)$.

Tabel 3

Gambaran tingkat stres mahasiswa

\begin{tabular}{lcc}
\hline \multicolumn{1}{c}{$\begin{array}{c}\text { Tingkat Stres } \\
\text { Mahasiswa }\end{array}$} & $\begin{array}{c}\text { Frekuensi } \\
(\mathbf{n})\end{array}$ & $\begin{array}{c}\text { Persentase } \\
(\mathbf{\%})\end{array}$ \\
\hline Tidak stres & 1 & 0,5 \\
Stres ringan & 94 & 47,2 \\
Stres sedang & 101 & 50,8 \\
Stres berat & 3 & 1,5 \\
\hline \multicolumn{1}{c}{ Total } & 199 & 100 \\
\hline
\end{tabular}

Tabel 3 diatas menunjukan hasil dari penelitian yang dilakukan pada 199 responden didapatkan sebagian besar responden mengalami tingkat stres sedang, dengan jumlah 101 responden $(50,8 \%)$.

\section{Analisa Bivariat}

Tabel 4

Hubungan antara penggunaan smartphone pada pagi hari terhadap tingkat stres mahasiswa

\begin{tabular}{|c|c|c|c|c|c|c|}
\hline \multirow{2}{*}{$\begin{array}{l}\quad \text { Variabel } \\
\text { Durasi } \\
\text { Pengunaan } \\
\text { Smartphone } \\
\text { Pada Pagi } \\
\text { Hari } \\
\end{array}$} & \multicolumn{4}{|c|}{ Tingkat Stres Mahasiswa } & \multirow[b]{2}{*}{ Total } & \multirow[b]{2}{*}{$\begin{array}{c}P \\
\text { value }\end{array}$} \\
\hline & $\begin{array}{c}\text { Tidak } \\
\text { stres } \\
\text { n } \\
\%\end{array}$ & $\begin{array}{c}\text { Stres } \\
\text { ringan } \\
\mathrm{n} \\
\%\end{array}$ & $\begin{array}{c}\text { Stres } \\
\text { sedang } \\
\mathrm{n} \\
\%\end{array}$ & $\begin{array}{c}\text { Stres } \\
\text { berat } \\
\text { n } \\
\%\end{array}$ & & \\
\hline $\begin{array}{l}\text { Durasi } \\
\text { singkat }\end{array}$ & $\begin{array}{c}1 \\
(0,9)\end{array}$ & $\begin{array}{c}70 \\
(65,4)\end{array}$ & $\begin{array}{c}36 \\
(33,6)\end{array}$ & $\begin{array}{c}0 \\
(0,0)\end{array}$ & $\begin{array}{c}107 \\
(100 \%)\end{array}$ & 0,00 \\
\hline Durasi lama & $\begin{array}{c}0 \\
(0,0) \\
\end{array}$ & $\begin{array}{c}24 \\
(26,1)\end{array}$ & $\begin{array}{c}65 \\
(70,7) \\
\end{array}$ & $\begin{array}{c}3 \\
(3,3) \\
\end{array}$ & $\begin{array}{c}92 \\
(100 \%)\end{array}$ & \\
\hline Total & $\begin{array}{c}1 \\
(0,5) \\
\end{array}$ & $\begin{array}{c}94 \\
(47,2)\end{array}$ & $\begin{array}{c}101 \\
(50,8)\end{array}$ & $\begin{array}{c}3 \\
(1,5) \\
\end{array}$ & $\begin{array}{c}199 \\
(100 \%)\end{array}$ & \\
\hline
\end{tabular}

Tabel 4 menggambarkan hubungan durasi penggunaan smartphone pada pagi hari dengan tingkat stres mahasiwa. Hasil analisa hubungan durasi penggunaan smartphone pada pagi hari dengan tingkat stres mahasiwa, didapatkan bahwa responden yang menggunakan smartphone secara singkat berjumlah 107 responden (53,8\%), dengan 1 responden $(0,9 \%)$ tidak mengalami stres, 70 responden $(65,4 \%)$ mengalami stres ringan, 36 responden $(37,6 \%)$ mengalami stres sedang dan tidak ada responden $(0,0 \%)$ yang mengalami stres berat. Responden dengan durasi pengunaan smartphone lama berjumlah 92 responden (46,2\%), dengan tidak ada responden $(0,0 \%)$ yang mengalami stres ringan, 24 responden $(26,1 \%)$ mengalami stres ringan, 65 responden $(70,7 \%)$ mengalami stres sedang dan 3 responden $(3,3 \%)$ mengalami 
Mohd. Ripa'i ${ }^{1}$, Safri' ${ }^{2}$, Yulia Irvani Dewi ${ }^{\mathbf{3}}$, Hubungan Durasi Penggunaan Smartphone pada Pagi Hari terhadap Tingkat Stres Mahasiswa Program Studi Ilmu Keperawatan Universitas Riau

stres berat. Berdasarkan hasil uji statistik yang digunakan yaitu uji korelasi Chi-Square didapatkan $p$ value $=0,000(\alpha<0,05)$ yang berarti dapat disimpulkan bahwa ada hubungan antara durasi penggunaan smartphone pada pagi hari dengan tingkat stres mahasiswa PSIK UR.

\section{PEMBAHASAN}

1. Karakteristik responden

a. Jenis kelamin

Penelitian ini menunjukkan hasil bahwa sebagian besar berjenis kelamin perempuan yaitu sebanyak 175 orang $(87,9 \%)$, sedangkan responden laki-laki hanya berjumlah 24 orang $(12,1 \%)$. Sesuai dengan populasi yang didapat dari data akademik PSIK UR yaitu perempuan lebih banyak dari pada laki-laki. Didukung oleh penelitian yang dilakukan oleh Demirci, Akgonul dan Akpinar (2015) yang mengatakan bahwa jumlah pengguna smartphone dengan jenis kelamin perempuan lebih banyak dibanding pengguna smartphone dengan jenis kelamin laki-laki. Hal ini dikarenakan perempuan memiliki keinginan yang lebih tinggi untuk berkomunikasi dari pada laki-laki yang mendorong mereka untuk selalu memeriksa smartphone hampir pada setiap waktu. Selain itu, perempuan berfikir dapat membina hubungan interpersonal yang baik melalui internet yang konsisten sehingga perempuan akan lebih sering dan lama menggunakan smartphone. Penggunaan tersebut lebih dari sekedar melakukan penggilan, bermain game atau memeriksa smartphone untuk mencari informasi namun perempuan juga menggunakan smartphone untuk secara teratur memeriksa situs jejaring sosial seperti Instagram dan Facebook.

Hasil penelitian ini sebanding dengan penelitian sebelumnya yang dilakukan oleh Park, Moon dan Yang (2014) bahwa perempuan memiliki risiko perilaku kecanduan smartphone lebih tinggi dibandingkan lakilaki. Hal ini dikarenakan perempuan relatif banyak menggunakan fitur-fitur yang terdapat pada smartphone dibandingkan laki-laki khususnya untuk keperluan berhubungan dengan banyak orang melalui jejaring sosial, aplikasi chatting, dan hiburan.

Sedangkan dalam perihal stres, perempuan lebih banyak mengalami stres dengan tingkat stres yang lebih tinggi dari pada laki-laki (Suwartika, Nurdin \& Ruhmadi, 2014). Pria cenderung menggunakan problemfocused coping karena pria biasanya menggunakan rasio atau logika selain itu pria terkadang kurang emosional sehingga mereka lebih memilih untuk langsung menyelesaikan masalah yang dihadapi atau langsung menghadapi sumber stres. Sedangkan pada wanita lebih cenderung menggunakan emotion-focused coping karena mereka lebih menggunakan perasaan atau lebih emosional sehingga jarang menggunakan logika atau rasio yang membuat wanita cenderung untuk mengatur emosi dalam menghadapi sumber stres atau melakukan koping. Selain itu, wanita sering merasa cemas ketika menghadapi 
masalah, sedangkan pada remaja pria ketika menghadapi masalah cenderung berperilaku agresif (Santrock, 2002 dalam Dewi, 2014).

b. Usia

Penelitian ini menunjukkan hasil bahwa rentang usia responden antara 18-21 tahun, dan sebagian besar responden berada pada usia 19 tahun yaitu sebanyak 75 orang $(37,7 \%)$. Ini didukung oleh data dari Platform smart data untuk mobile marketing and e-commerce, merilis data terbaru perihal Smartphone User Personal Report (SUPR) atau laporan personal pengguna smartphone di Indonesia untuk tahun 2015. Dalam laporan tersebut pengguna smartphone direntang usia dibawah 30 tahun lebih besar, yakni sekitar 61\% (Hasan, 2015). Penelitian yang dilakukan oleh Emelin, Tkhostov dan Rasskazova (2013) mengatakan bahwa psikologis remaja merupakan salah satu faktor utama remaja beresiko lebih tinggi untuk mengalami kecanduan smartphone dibandingkan kelompok usia yang lebih tua.

Mahasiswa memiliki banyak kegiatan pembelajaran dan mencari informasi dengan menggunakan smartphone sebagai media atau alat bantu, termasuk juga penggunaan smartphone untuk kegiatan lain seperti mendengarkan musik, browsing, menggunakan media sosial, menonton, dan bermain game. Banyaknya kegiatan yang dapat dilakukan dengan smartphone, lamakelamaan akan dapat menimbulkan berbagai keluhan kesehatan salah satunya ialah stres.
2. Gambaran durasi penggunaan smartphone pada pagi hari

Dari hasil penelitian yang dilakukan didapatkan sebagian besar responden menggunakan smartphone dengan durasi singkat ( $\leq 93,28$ menit), dengan jumlah 107 responden $(53,8 \%)$. Smartphone didefinisikan sebagai perangkat posel yang memiliki fiturfitur yang melebihi ponsel pada umumnya. Karena smartphone memiliki fitur tambahan selain alat komunikasi, seperti Personal Information manager (PIM), dukungan penambahan aplikasi, serta memiliki sistem operasi yang mendukung berbagai fitur multimedia dan kebuhan bisnis (Ferdiana, 2008). Smartphone menjadi sorotan karena memiliki kecanggihan dalam berbagai hal serta fungsinya yang efektif dan efisien yang dapat digunakan kapan saja dan dimana saja (Resti, 2015).

Smartphone merupakan benda yang pertama kali penggunanya lihat pada pagi hari dan yang terakhir dilihat sebelum tidur (Thomee et al., 2011). Penelitian yang dilakukan oleh Haug, Castro, Kwon, Filler, Kowatsch dan Schaub (2015) menyatakan bahwa durasi pemakaian smartphone yang lebih singkat adalah dipagi hari. Durasi penggunaan smartphone mahasiswa PSIK UR yang singkat ini dapat dikarenakan jadwal kuliah yang padat sehingga pengguna hanya menggunakan smartphone nya hanya untuk melihat informasi penting, sehingga penggunaannya hanya sebentar. 
Mohd. Ripa'i ${ }^{1}$, Safri' ${ }^{2}$, Yulia Irvani Dewi ${ }^{\mathbf{3}}$, Hubungan Durasi Penggunaan Smartphone pada Pagi Hari terhadap Tingkat Stres Mahasiswa Program Studi Ilmu Keperawatan Universitas Riau

\section{Gambaran tingkat stres mahasiswa}

Hasil penelitian ini menunjukan sebagian banyak responden mengalami tingkat stres sedang, dengan jumlah 101 responden $(50,8 \%)$. Penelitian ini, sejalan dengan penelitian yang dilakukan oleh Kenantie, Hernawaty dan Hidayati (2012) yang mengatakan bahwa sebagian besar tingkat stres pada remaja berada pada tingkat stres sedang yang dapat dipengaruhi oleh pola emosi remaja yang masih belum matang.

Penelitian lain yang dilakukan oleh Park, Moon dan Yang (2014) juga menunjukkan keadaan psikologis remaja relatif belum stabil dikarenakan masih proses mencari jati diri sehingga aktualisasi diri kurang optimal. Hasil penelitian yang dilakukan Sharma (2012) menyatakan bahwa anak muda merupakan basis utama perkembangan teknologi dan merupakan kelompok usia yang sangat aktif menggunakan smartphone serta cenderung tidak dapat lepas dari smartphone sepanjang hari.

Chiu (2014) menyebutkan bahwa life stress terjadi pada kehidupan mahasiswa, sehingga dapat membuat smartphone sebagai pelarian. Tidak adanya kontrol diri yang kuat terhadap pemakaian smartphone sehingga sebagai awal mula terjadinya ketergantungan akan alat komunikasi tersebut (smartphone addiction). Smartphone juga berfungsi untuk menghasilkan kesenangan dan menghilangkan perasaan stres untuk sementara waktu, namun apabila gagal untuk mengendalikan atau membatasi penggunaan akan memiliki konsekuensi yang membahayakan (Van Deursen, 2015).

Penggunaan yang berlebihan dan kebiasaan memeriksa smartphone dapat mengakibatkan penggunaan menjadi kompulsif. Penggunaan kompulsif dan berlebihan dapat menyebabkan gejala kesehatan mental seperti gangguan tidur dan depresi (Thomée, Härenstam \& Hagberg, 2011). Kecanduan smartphone sangat berhubungan dengan durasi penggunaan, orang dengan kecanduan smartphone memiliki waktu yang lebih banyak untuk beraktivitas menggunakan smartphone nya (Mulya, 2017). Selain karena durasi kecanduan dari penggunaan smartphone, menurut Norisanto (2015) stres dari penggunaan smartphone juga dapat disebabkan karena beberapa hal diantarnya adalah sinyal yang kurang bagus, gangguan dari group chat yang berisik, battery dan kuota yang cepat habis, urusan kantor yang berhubungan dengan smartphone dan penggunaan fitur media sosial yang terdapat pada smartphone. Penyebab stres pada mahasiswa juga berhubungan dengan masalah pada orang tua, akademik dan teman sebaya (Nasution, 2007).

4. Hubungan antara durasi penggunaan smartphone pada pagi hari dengan tingkat stres mahasiswa

Hasil analisa hubungan durasi penggunaan smartphone pada pagi hari dengan tingkat stres mahasiwa, didapatkan bahwa 
responden yang menggunakan smartphone secara singkat berjumlah 107 responden $(53,8 \%)$, dengan 1 responden $(0,9 \%)$ tidak mengalami stres, 70 responden $(65,4 \%)$ mengalami stres ringan, 36 responden $(37,6 \%)$ mengalami stres sedang dan tidak ada responden $(0,0 \%)$ yang mengalami stres berat. Responden dengan durasi pengunaan smartphone lama berjumlah 92 responden $(46,2 \%)$, dengan tidak ada responden $(0,0 \%)$ yang mengalami stres ringan, 24 responden (26,1\%) mengalami stres ringan, 65 responden $(70,7 \%)$ mengalami stres sedang dan 3 responden $(3,3 \%)$ mengalami stres berat. Peneliti menggunakan uji korelasi Chi-Square dan didapatkan $p$ value $=0,000(\alpha<0,05)$ yang menunjukan ada hubungan antara durasi penggunaan smartphone pada pagi hari dengan tingkat stres mahasiswa.

Penelitian ini sejalan dengan penelitian yang dilakukan oleh Samaha dan Hawi (2016) menunjukkan adanya hubungan positif antara kecanduan smartphone dan stres. Jika resiko kecanduan smartphone meningkat, maka stres yang dirasakan diperkirakan juga akan meningkat. Kecanduan smartphone sangat berhubungan dengan durasi penggunaan, orang dengan kecanduan smartphone memiliki waktu yang lebih banyak untuk beraktivitas menggunakan smartphone nya (Mulya, 2017). Penelitian yang dilakukan oleh Sharma (2012) menyatakan bahwa sekitar $85 \%$ remaja masa kini lebih memilih menghabiskan waktu luang dengan menggunakan smartphone dibandingkan beraktivitas diluar seperti olahraga.

Penelitian oleh Demirci, Akgonul dan Akpinar (2015) menunjukan bahwa penggunaan smartphone berhubungan positif dengan depresi, kecemasan dan kualitas tidur. Efek dari perilaku kecanduan smartphone terhadap depresi, kecemasan dan kualitas tidur terkait dengan penggunaan smartphone secara berlebihan dapat menyebabkan masalah pada mahasiswa. Selain gangguan tersebut, gangguan lain yang dapat terjadi adalah technostress (Charles, Piazza, Mogle, Sliwinski \& Almeida, 2013). Technostress adalah ketidaknyamanan secara fisik maupun psikologis yang timbul akibat individu tidak bisa beradaptasi dengan kondisi teknologi informasi saat ini. Selain itu juga, individu memiliki ketergantungan yang berlebihan dengan berbagai teknologi (Nurfadilah, 2014).

Smartphone merupakan benda yang pertama kali penggunanya lihat pada pagi hari dan yang terakhir dilihat sebelum tidur (Thomee et al., 2011). Pada pagi hari, AdrenoCorticoTropic Hormone (ACTH) meningkat dan mencapai titik terendah pada saat malam hari (Bornstein, Allolio, Arlt, Barthe \& DonWauchope, 2016). Ini terjadi dalam ritme sirkadian manusia. Ritme sirkadian dapat dipengaruhi oleh cahaya, gravitasi, stimulus elektromagnetik dan lain-lain. ACTH merupakan hormon yang akan beraksi pada korteks adrenal yang kemudian akan memproduksi kortisol sebagai pemicu 
Mohd. Ripa'i ${ }^{1}$, Safri' ${ }^{2}$, Yulia Irvani Dewi ${ }^{\mathbf{3}}$, Hubungan Durasi Penggunaan Smartphone pada Pagi Hari terhadap Tingkat Stres Mahasiswa Program Studi Ilmu Keperawatan Universitas Riau

terjadinya stres (Breivik, 2000 dalam Boyati, 2007).

Penelitian yang dilakukan oleh Mahdavi, Sahraei, Yaghmaei dan Tavakoli (2014), menemukan adanya peningkatan ACTH setelah diberikan gelombang elektromagnetik pada seekor tikus. Peningkatan ACTH tersebut ditandai dengan gejala seperti gelisah yang mengindikasikan terjadinya stres. Stres tersebut dapat mengakibatkan teraktivasinya Hypothalamic-Pituitary Adrenal Axis (HPAaxis). Kemudian hipotalamus yang terpicu oleh stresor akan mensekresi Corticotrophin Releasing Hormone (CRH) dan Arginin Vasopressin (AVP). Sekresi CRH akan menstimulasi korteks adrenal untuk mensekresi kortisol sebagai hormon pemicu stres (Dewi \& Wulan, 2015). Stres adalah sebuah reaksi terhadap stimulus yang mengganggu keseimbangan fisik atau mental dan merupakan bagian dari sebuah kehidupan (Psychology Today, 2017).

\section{SIMPULAN}

Hasil penelitian menunjukkan bahwa karakteristik responden paling banyak berada pada usia 19 tahun yaitu sebanyak 75 orang $(37,7 \%)$ dengan jenis kelamin sebagian besar adalah perempuan yaitu sebanyak 175 orang $(87,9 \%)$. Penelitian ini juga menunjukan sebagian besar responden menggunakan smartphone pada pagi hari (pukul 04:00-11:00 WIB) dengan durasi singkat, yakni berjumlah 107 responden $(53,8 \%)$. Sedangkan pada

tingkat stres responden, didapatkan sebagian besar responden mengalami tingkat stres sedang, dengan jumlah 101 responden (50,8\%). Hasil uji statitistik yang diperoleh dengan uji Chi-Square didapatkan bahwa $p$ value $=0,000$, hal ini menunjukkan bahwa nilai $p$ value yang didapat lebih kecil dari $\alpha=$ $0,05(5 \%)$. Sehingga dapat disimpulkan bahwa terdapat hubungan antara durasi penggunaan smartphone pada pagi hari terhadap tingkat stres mahasiswa PSIK UR.

\section{SARAN}

1. Pengembangan Ilmu Keperawatan

Hasil penelitian ini agar dapat dijadikan sebagai literatur dalam ilmu keperawatan untuk mengetahui tingkat stres pada mahasiswa PSIK UR.

2. Institusi

Institusi beserta mahasiswa diharapkan agar dapat menjadikan penelitian ini sebagai sumbangan ilmiah dalam rangka mengembangkan pengetahuan, menambah informasi dan wawasan mengenai dampak durasi penggunaan smartphone yang lama terhadap stres.

3. Masyarakat (termasuk mahasiswa)

Hasil penelitian ini diharapkan dapat menjadi pemberi informasi mengenai penggunaan smartphone untuk dapat mencegah atau meminimalkan munculnya stres. 


\section{Peneliti Berikutnya}

Hasil penelitian ini diharapkan dapat menjadi referensi oleh peneliti berikutnya untuk meneliti fenomena mengenai penggunaan smartphone dan stres. Selain itu, peneliti selanjutnya dapat lebih menspesifikan jenis sumber radiasi, jarak sumber radiasi terhadap tubuh, mengukur durasi dalam sehari dan mengukur kadar ACTH dari responden.

\section{DAFTAR PUSTAKA}

Azrul, N. (2016). Hubungan durasi penggunaan smartphone sebelum tidur dengan kualitas tidur mahasiswa PSIK $U R$. Skripsi. Universitas Riau.

Backer, E. (2010). Using smartphones and facebook in a major assessment: the student experience. e-Journal of Business Education \& Scholarship of Teaching. 4(1). 14-31.

Bornstein, S. R., Allolio, B., Arlt, W., Barthel, A., Don-Wauchope, A., Hammer, G. D., Husebye, E. S., Merke, D. P., Murad, M. H., Stratakis, C. A., \& Torpy, D. J. (2016). Diagnosis and treatment of primary adrenal insufficiency: an endocrine society clinical practice guideline. The Jurnal Clinical Endocrinolgy and Metabolism. 1-26.

Boyapati, L., \& Wang, H. (2007). The role of stress in periodontal disease and wound healing. Periodontology. 44. 195-210.

Charles, S. T., Piazza, J. R., Mogle, J., Sliwinski, M. J., \& Almeida, D. M. (2013). The wear and tear of daily stressors on mental health. Psychological Science. 24(5). 733-741

Chiu, S. (2014). The relationship between life stress and smartphone addiction on Taiwanese university student: A meditation model of learning self efficacy and social efficacy. Computers in Human Behavior. (34). 49-57.

Demirci, K., Akgonul, M., \& Akpinar, A. (2015). Relationship of smartphone use severity with sleep quality, depression, and anxiety in university student. Journal of Behavioural Addictions, 4(2), 85-92.

Dewi, I. K., \& Wulan, A. J. (2015). Efek paparan gelombang elektromagnetik handphone terhadap kadar glukosa darah. Majority. Vol. 4(7). 31-38

Dewi, K., A. (2014). Perbedaan coping stress pada perawat pria dan wanita. Jurnal Psikologi Kepribadian. 1-16.

Emelin, V., Tkhostov, A., \& Rasskazova, E. (2013). Excessive use of internet, mobile phones and computers: the role of technology-related changesin needs and psychological boundaries. Procedia Social and Behavioral Sciences 86. 530535.

Ferdiana, R. (2008). Membangun aplikasi smartclient pada platform Windows Mobile. Jakarta: PT Elex Media Komputindo.

Hasan, W. N. (2015). Pengguna smartphone di Indonesia lebih banyak berusia kurang dari 30 tahun. Diperoleh tanggal 28 Maret 2017 dari, https://arenalte.com/berita/industri/penggu na-smartphone-indonesia/.

Haug, S., Castro, R, P., Kwon, M., Filler, A., Kowatsch, T., Schaub, M. P. (2015). Smartphone use and smartphone addiction among young people in Switzerland. Journal of Behavioral Addictions. 4(4). 299-307.

Hidayat, A. A. A. (2007). Riset keperawatan dan teknik penulisan ilmiah. Jakarta: Salemba Medika.

Keminfo. (2013). Indonesia raksasa teknologi asia. Diperoleh 13 Desember 2016 dari, https://kominfo.go.id/content/detail/6095/i ndonesia-raksasa-teknologi-digitalasia/0/sorotan_media.

Kenantie, O. A., Hernawaty, T., \& Hidayati, N. O. (2012). Gambaran tingkat stres Siswa SMAN 3 Bandung kelas XII menjelang Ujian Nasional 2012. Skripsi. Universitas Padjadjaran

Kure, E. (2015). Mayoritas netizen di indonesia berusia 18-25 tahun. Diperoleh tanggal 28 Maret 2017 dari, http://www.beritasatu.com/digitallife/261297-mayoritas-netizen-diindonesia-berusia-1825-tahun.html. 
Mohd. Ripa'i ${ }^{1}$, Safri' ${ }^{2}$, Yulia Irvani Dewi ${ }^{\mathbf{3}}$, Hubungan Durasi Penggunaan Smartphone pada Pagi Hari terhadap Tingkat Stres Mahasiswa Program Studi Ilmu Keperawatan Universitas Riau

Mahdavi, M. S., Sahraei, H., Yaghmaei, P., \& Tavakoli, H. (2014). Effects of electromagnetic radiation exposure on stress-related behaviors and stress hormones in male wistar rats. Biomolecules \& Therapeutics. 22(6). 570576.

Mulya, S. (2017). Batasi durasi pengunaan smartphone milik anak dari jarak jauh. Diperoleh tanggal 09 Juli dari http://daftarandroid.com/batasi-durasipenggunaan-smartphone-milik-anak-darijarak-jauh/.

Nasution, I., K. (2007). Stres pada remaja. Makalah. Medan: Universitas Sumatera Utara

Norisanto. (2015). Apa benar smartphone membuat pemakainya jadi stres. Diperoleh tanggal 26 Juli 2017 dari, http://www.norisanto.com/mobile/apabenar-smartphone-membuat-pemakainyajadi-stres/

Notoatmodjo, S. (2010). Metodologi penelitian kesehatan. Jakarta: Rineka Cipta.

Nurfadilah, R. (2014). Technostress. Di peroleh 2 Februari 2017 dari, https://prezi.com/rjd7oyw88c6/technostress/.

Oulasvirta, A., Rattenbury, T., Ma, L., \& Raita, E. (2012). Habits make smartphone use more pervasive. Pers Ubiquit Comput. 16. 105-114.

Park, G., Moon, G., \& Yang, D. (2014). The moderation effect of smart phone addiction in relationship between selfleadership and innovative behavior. International Journal of Social, Behavioral, Educational, Economic, Business and Industrial Engineering. 8(5). 1307-1310.

Prayogi. (2014). Pengguna smartphone indonesia peringkat kelima dunia. Republika.co.id. Diperoleh 4 Desember 2015 dari, http://www.republika.co.id/berita/trendtek /gadget/14/11/02/neehfh-pengguna- smartphone-indonesia-peringkat-kelimadunia.

Psychology Today. (2017). Stress. Diperoleh 2 Februari 2017 dari, https://www.psychologytoday.com/basics/ stress.

Resti. (2015). Penggunaan smartphone dikalangan mahasiswa Fakultas Ilmu Sosial dan Ilmu Politik Universitas Riau. Jom FISIP. 2(1). 1-15.

Salam, D. (2015). Pengguna smartphone capai dua miliar orang. Marketeers. Diperoleh 28 Desember 2016, dari http://marketeers.com/article/penggunasmartphone-capai-dua-miliar-orang.html.

Samaha, M., \& Hawi, N. S. (2016). Relationships among smartphone addiction, stress, academic performance, and satisfaction with life. Computers in Human Behavior. 321-325.

Setiadi. (2013). Konsep dan praktek penulisan riset keperawatan (2ed). Yogyakarta: Graha Ilmu.

Sharma, M. (2012). Addiction of youth towards gadgets. Elixir Human Res. Mgmt. 42A. 6568-6572.

Suwartika, I., Nurdin, A., \& Ruhmadi, E. (2014). Analisis faktor yang berhubungan dengan tingkat stres akademik mahasiswa reguler program studi DII keperawatan cirebon poltekkes kemenkes tasikmalaya. Jurnal Keperawatan Soedirman (The Soedirman Journal of Nursing). 9(3). 173189.

Thomée, S., Härenstam, A., \& Hagberg, M. (2011). Mobile phone use and stress, sleep disturbances, and symptoms of depression among young adults - a prospective cohort study. BMC Public Health. 1-14.

Van Deursen, A. J. A. M., Bolle, C. L., Heghner, S. M. \& Kommers, P. A. M. (2015). Modelling habitual and addictive smartphone behaviour the role of smartphone usage types, emotional intelligence, social stress self regulation, age and gender. Journal Computer in Human Behaviour. 411-420. 